\title{
CHARACTERIZATION OF NICKEL GRAPHITE SEALING COATINGS IN THE SYSTEM WITH THE NICKEL - ALUMINUM BONDING COATING
}

\author{
Mihajlo R. Mrdak, Research and Development Center \\ IMTEL Communications a. d., Belgrade
}

FIELD: Chemical Technology

DOI: 10.5937/vojtehg61-1574

ARTICLE TYPE: Original Scientific Paper

\section{Summary:}

This study shows the mechanical and structural characteristics of the $\mathrm{Ni}$ - graphite sealing and the effect of its use in the low and high pressure compressor parts in a TV2-117A turbojet engine. The coatings were deposited through the atmospheric plasma spray (APS) process. The sealing materials were substituted on the compressor working ring, compressor focusing devices and the compressor front body in a TV2-117A turbojet engine to ensure a maximum air flow in a temperature range from 100 to $125^{\circ} \mathrm{C}$ through the compressor at a pressure of 7 bars. Soft seals are formed as double systems consisting of a lower bond layer based on the NiAl coating and upper sealing layers of coatings based on $\mathrm{Ni}-25 \%$ graphite and $\mathrm{Ni}-$ $15 \%$ graphite. The microstructure of the layers was examined using the light microscope. The morphology of $\mathrm{Ni}$ - graphite powder particles and the fracture morphology of the coatings were investigated using a Scanning Electron Microscope (SEM). The microstructural analysis of the deposited layers was performed according to the Pratt-Whitney standard. The mechanical properties of the coatings were assessed by testing the microhardness of the bond layers using the $\mathrm{HV}_{0.3}$ method and by testing the macrohardness of the sealing layers using the HR15y method. The strength of the bonds of coating double systems was tested using the tensile testing.The compressor part sealing effect was tested within the TV2-117A engine.

Key word: atmospheric plasma spray (APS), sealing, microstructure, interface, microhardness, macrohardness, bond strength.

\section{Introducion}

New generations of turbo-jet engines have to meet increasing demands for better reliability and longer work in exploitation. The goal of turbo-jet engine design is based on considerable driving force, high

\footnotetext{
* The author is thankful for the financial support from the Ministry of Education and Science of the Republic of Serbia (national projects OI 174004, TR 34016).

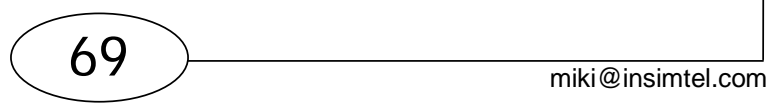


efficiency and lower fuel consumption. In order to achieve the objectives, the clearance between the rotor blades and the engine housing must be small (Demasi, 1994, pp. 1-9).Very good sealing of the gas flowing through the engine reduces gas losses due to leakage. Thermal spray processes are commonly used for sealing coatings because of a simple process, component repairs, easy setup and good sealing efficiency (Novinski, 1991, pp. 451-454). Also, the seals can provide thermal insulation of the casing, and reduce the impact of gas and fuel high temperature on the housing (Novinski, 1991, pp. 451-454), (Yi, 1999, pp. 47-53). Multicomponent powders used for sealing coatings production are applied for this purpose.The chemical composition of coatings mainly consists of a metal phase and a non-metallic phase of self - lubrication with high porosity (Oka, 1990, pp. 58-67). The most important properties that sealing coatings should have are high resistance to abrasion and scraping blade erosion resistance to gas and foreign particles present in the gas (Novinski, 1990, pp. 151-157), (Yi, 1997, pp. 99-102). Plasma spray coatings and plasma technology have a leading role in the technological process of protection of new aviation parts and repairs of jet engine motors. Today plasma spray coatings are widely applied to aircraft components of low and high: pressure such as landing gear components, pressure compressors and gas turbine components (Nasr, 1988, pp. 75-84). Soft coatings are applied on the components of low and high pressure turbojet engine compressors because they are resistant to erosion and together with blades create low energy wear conditions.Coatings are designed to wear during operation without causing wear and damage to the blades or labyrinth seals. Coatings are structurally suitable for eccentric assemblies because they can compensate for changes in tolerancies caused by machining. Nickelgraphite-based coatings enable clearance setting to the lowest value thus enhancing engine performances. Precision in machining tolerance significantly reduces damage to the blades and fuel consumption. Most frequently used abrasive coatings in the temperature range of $227^{\circ} \mathrm{C}-627^{\circ} \mathrm{C}$ are: nickel - graphite, aluminum - boron nitride, nickel - chromium - iron and aluminum - silicon - polyester A choice of powders depends on the material conditions of exploitation and the physical-chemical properties of parts. The quality and the resource of coatings depend on deposition parameters. Sealing coating systems are designed to take into account the eccentricity rotor and dimensional changes caused by changes in the coating temperature. Sealing systems are designed to wear without leaving damage to the blade tops, and to maintain a constant gap (Tosnar, 1988, pp. 257-262). Blade materials and soft sealing materials are parellelly developed in order to achieve optimum characteristics of the wear of blade peaks and seals. At high speeds, the blade peaks must 
act as efficient cutting tools. This is necessary in order to avoid damaging the gasket or the blades, which can lead to blade breakage if there is no effective cutting. The material should be highly resistant to erosion caused by foreign particles; it should wear without causing damage to the blades and withstand operating temperatures without affecting mechanical properties (Nasr, 1988, pp. 75-84). In wearable sealing systems, it is necessary to achieve a balance between material wear due to high temperatures, final machining, resistance to erosion and resistance to wear. The plasma spray powder deposition parameters enable the control of these critical characteristics. The plasma spray deposition process enables the control of porosity, density and thickness of coatings in order to obtain the required characteristics of sealant layers (Tosnar, 1988, pp. 257-262).

Soft sealings are formed as double syistems. NiAl composite powder particles are commonly used for a lower bonding layer. Al-coated $\mathrm{Ni}$ particles enable the exothermic reaction with the release of heat which increases the bond strength of the coating with the substrate and the top coating (Deevi,et al., 1997, pp. 335-344). The Ni/Al coated powder gives coatings which consist of free-Al, $\alpha-\mathrm{Ni}$ solid solution and $\mathrm{NiO}$ and $\mathrm{Al}_{2} \mathrm{O}_{3}$ oxides (Svantesson, Wigren, 1992).The thickness values of the binding layer must be consistent with the basic material of the substrate and the upper layer.The role of the binding layer is to provide good adhesion with the base material and a bond with the upper sealing layer.

The main function of the outer layer is sealing. Metco 307NS and 308NS powders are used for sealing coatings applied at $480^{\circ} \mathrm{C}$, with high resistance to oxidation, wear and sudden changes in temperature (Metco 307NS, Metco 308NS Nickel Graphite Powder, 2000, Technical Bulletin 10-115). Thus formed soft seals provide an effective sealing with a minimum gap during engine operation and reduce the pressure losses in the compressors and turbine sections. Metco 307NS and 308NS powders consist of $75 \% \mathrm{Ni} / 25 \%$ graphite and $\mathrm{Ni} 85 \% / 15 \%$ graphite. The chemical composition of Metco 308NS powder is identical and only differs in the graphite content and the particle size distribution within the range of 30-90 $\mu \mathrm{m}$. Powders include a metal component i.e. nickel that provides toughness and a non-metallic component i.e.graphite that serves as a solid lubricant (Metco 307NS, Metco 308NS Nickel Graphite Powder, 2000, pp. 10-115). Metco 307NS and 308 NS powders are certified by Pratt \& Whitney aerospace company with the specifications PWA1352-1 and PWA1352-2. The powder is recommended for sealing parts such as rings and working compressor housings with an air flow of certain temperature.

Coatings are applied to the inner and outer surfaces of compressors of low, medium and high pressure. Prior to the powder deposition, the 
substrate is preheated at a temperature ranging from 90 to $120^{\circ} \mathrm{C}$. The preheating temperature is very important as well as the temperature control during the powder deposition since it significantly influences the hardness of deposited layers, the proportion of pores and the coating and substrate bond strength. Preheating the substrate increases the bond macrohardness and strength while reducing coating porosity. The substrate temperature during deposition should not exceed $180^{\circ} \mathrm{C}$. Depending on the deposition parameters and equipment, Metco (5P, 6P and 6P-II) coatings have macrohardness in the range of 30-70 HR15y (Metco 307NS, Metco 308NS Nickel Graphite Powder, 2000, pp. 10-115). Coatings containing micropores with a share of $15 \%$ to $25 \%$ depend on the deposition parameters and eqipment types. Sealing coatings are always deposited in a binary system with Metco 450NS bonding coating because of higher bond strength values (Metco 450NS Nickel /Aluminum Composite Powder, 2000, pp. 10-136).

The aim was to use the plasma spray technology and nickel graphite coatings for testing the effectiveness of the sealing of TV2-117A turbojet engines compressors.

World research in this area has resulted in the application of $\mathrm{Ni}$ graphite coatings in the repair of TV2-117A turbojet engine compressors. The existing sealant has been replaced on the compressor work rings, focusing devices and the front compressor body. Compressor tests have confirmed that the new sealing system provides the maximum air flow of $100-125^{\circ} \mathrm{C}$ through the compressor at a pressure of 7 bar with improved fuel economy.

\section{Materials and experimental details}

The substrate material for depositing double sealing systems of coatings for testing mechanical and structural characteristics was $\mathrm{X} 15 \mathrm{Cr} 13$ stainless steel (EN 1.4024). The material was used in the thermally untreated state. The Metco 450NS powder of the Sulzer Metco company was used for bonding layers. The powder consists of $95.5 \%$ nickel and $4.5 \% \mathrm{Al}$ granules with a range of powder particles from 45 to $88 \mu \mathrm{m}$ (Metco 450NS Nickel /Aluminum Composite Powder, 2000, pp. 10-136). The coatings are self-binding and dense with high values of bond strength. The powders with Metco 307NS and Metco 308NS designations were used for the production of sealing coatings. Powder particles consist of graphite cores coated with fine particles of nickel. The Metco $307 \mathrm{NS}$ powder consists of $75 \% \mathrm{Ni}$ and $25 \%$ graphite with a range of powder particle granules from 30 to $90 \mu \mathrm{m}$. The powder melting temperature is $1455^{\circ} \mathrm{C}$. The Metco $308 \mathrm{NS}$ powder is chemically identical 
but differs in graphite content and distribution of particle size within the range of $30-90 \mu \mathrm{m}$. The powder $308 \mathrm{NS}$ consists of $85 \% \mathrm{Ni}$ and $15 \%$ graphite with the same melting temperature as the Metco 307NS powder (Metco 307NS, Metco 308NS Nickel Graphite Powder, 2000, pp. 10-115). Fig. 1 gives a SEM photomicrograph showing the morphology of $\mathrm{Ni}-25 \%$ graphite powder particles. The powder particles are irregular in shape. The graphite particles are surrounded by light gray nickel.

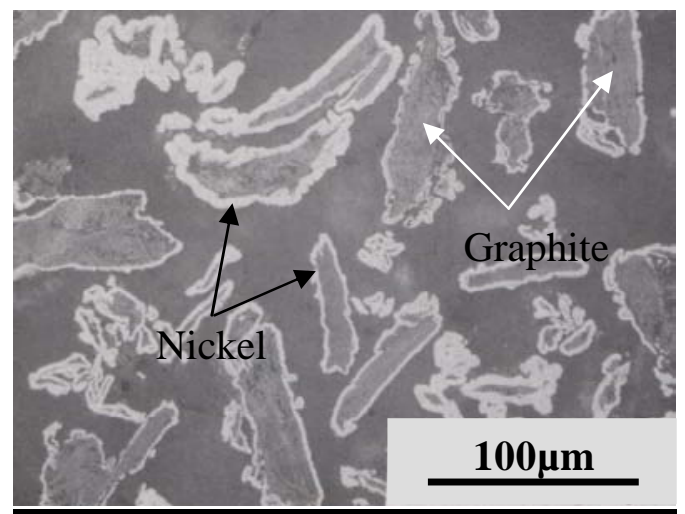

Slika 1 - (SEM) Skening elektronska mikrografija čestica praha Ni-25\% grafit Figure 1 - (SEM) Scanning electron micrograph of $\mathrm{Ni}-25 \%$ graphite powder particles

The deposition powder manufacturer recommends the equipment with the label Metco (5P, 6P and 6P-II) that uses a mixture of acetylene and oxygen as an energy source, not excluding the possibility of using the atmospheric plasma spray equipment The powder manufacturer has regulated the powder deposition parameters and the characteristics of the produced coatings for the particular equipment. Secondary plasma gas is not applied in plasma spray systems. Arc plasma energy, defined by the gas flow and amperage, is applied for powder melting, thus preventing graphite burning and change in the powder composition. Coatings were applied on the samples and the compressor parts by the plasma spray process at the atmospheric pressure (APS).Coatings were applied to the samples and the parts previously abraded with white corundum with particle sizes from 0.7 to $1.5 \mathrm{~mm}$. Before deposition, the bases were preheated at temperatures from 90 to $120^{\circ} \mathrm{C}$. The atmospheric plasma spray (APS) system of the Plasmadyne firm was used for the production of coatings. Due to the geometry of the focusing device (IV-IX level), the front compressor body and compressor rings (V-X level), powder deposition was done with a special plasma gun MINI-GUN II with the dimensions $\Phi 25 \times 600 \mathrm{~mm}$. The plasma gun consisted of the anode A 2084-F65, the cathode K 1083-129 and the gas injector GI 
2084 B-103. Bonding layers were deposited with a plasma gas mixture of Ar-He. Argon was used as a gas for depositing Ni-graphite particles with electric currents of $600 \mathrm{~A}, 650 \mathrm{~A}$ and $700 \mathrm{~A}$. On the samples for testing the characteristics of coatings, the bonding NiAl layers were deposited with the share of deposits of 0.025 microns per single plasma gun pass with a total thickness of $0.15 \mathrm{~mm}$. The sealing Ni-graphite layers were deposited with the share of deposits of $0.12 \mathrm{~mm}$ in a single plasma gun pass with a total thickness of $0.36 \mathrm{~mm}$. The Ni-25\% graphite coating is deposited on the front of the compressor body, while the Ni-15\% graphite coating is deposited.on the compressor working rings and focusing devices. The coatings deposited on the compressor parts had a total thickness of $2.3 \mathrm{~mm}$. The detailed values of spray parameters are shown in Table 1.

Table 1 - Plasma spray parameters

Tabela 1 - Plazma sprej parametri

\begin{tabular}{|c|c|c|c|}
\hline Deposition parameters & NiAl & $\begin{array}{c}\text { Ni -25\% } \\
\text { graphite }\end{array}$ & $\begin{array}{c}\text { Ni -15\% } \\
\text { graphite }\end{array}$ \\
\hline Electric current (A) & 800 & $700 / 650 / 600$ & $700 / 650 / 600$ \\
\hline Arc voltage (V) & 39 & $34 / 32 / 31$ & $34 / 32 / 31$ \\
\hline Primary Ar plasma gas (I/ min) & 75 & 54 & 54 \\
\hline Secondary plasma gas He (I/ min) & 50 & - & - \\
\hline Carrier Ar gas flow (I/ min) & 7 & 9 & 9 \\
\hline Rotation of the disk (r/min) & 2.5 & 3.2 & 3.2 \\
\hline Plasma gun distance (mm) & 60 & 65 & 65 \\
\hline Extensive work speed $(\mathrm{mm} / \mathrm{s})$ & 500 & 250 & 250 \\
\hline Plasma gun feed rate $(\mathrm{mm})$ & 3 & 3 & 3 \\
\hline \multicolumn{2}{|r}{}
\end{tabular}

Mechanical and microstructural characterizations of the obtained coatings were carried out according to the Pratt \& Whitney standard (Turbojet Engine - Standard Practices Manual, 2002). Rectangular samples of $70 \times 20 \times 1.5 \mathrm{~mm}$ were used for the measurement of hardness and metallographic tests, while the tensile strength was tested on cylindrical samples of $\varnothing 25 \times 50 \mathrm{~mm}$. The microstructure analysis of the coatings was conducted on a light microscope, while the powder morphology and coating fracture morphology were carried out on the SEM (Scanning Electron Microscope).

The microhardness of binding layers was measured using a Vickers diamond pyramid indenter and $300 \mathrm{~g}$ load $\left(\mathrm{HV}_{0.3}\right)$. The measurement was carried out in the direction along the lamellae, in the middle and at the ends of the sample. Three readings were conducted at three points and the results were averaged.

The macrohardness of Ni-graphite coatings was performed using a Rockwell steel ball of $12.7 \mathrm{~mm}$ in diameter and a load of 15kg (HR15y). 
The macrohardness of coatings was measured along the layers.To assess the homogeneity of the layers, the measurements were carried out in three points: in the middle, on the left and on the right end of the samples. The presented macrohardness results are the averaged values of the majority of measurements.

The tests of tensile bond strength were carried out at room temperature on hydraulic equipment with a speed of $10 \mathrm{~mm} / \mathrm{min}$, for all sample tests. The geometry of the samples is in accordance with ASTM C633 standard. For each group of samples, three test specimens were tested and the results were averaged.

\section{Results and discussion}

The values of microhardness of $\mathrm{NiAl}$ bonding layers were in the range of 203-210HV0.3 and above the values of the standard PWA (min.140 HV ..3) (Turbojet Engine - Standard Practices Manual, 2002). This implies that during the deposition process there was a complete reaction of $\mathrm{Al}$ and $\mathrm{Ni}$ particles. The values of macrohardness of $\mathrm{Ni}$ graphite layers are shown in Fig. 2 and the bond strength of the system NiAl / Ni-graphite coating in Fig. 3. The electric current values that are directly related to the plasma gun power supply affected the values of the macrohardness and the bond strength of the deposited layers. The layers deposited with the lowest amperage of $600 \mathrm{~A}$ showed the lowest value of macrohardness of $62 \mathrm{HRY}$ for $\mathrm{Ni}-25 \%$ graphite and $65 \mathrm{HRY}$ for $\mathrm{Ni}-15 \%$ graphite coatings. The highest macrohardness value of $68 \mathrm{HRY}$ for $\mathrm{Ni}-25 \%$ graphite and $70 \mathrm{HRY}$ for $\mathrm{Ni}-15 \%$ graphite coatings occured in the layers deposited with the highest value of electric current of 700A. For all deposited coatings, the obtained macrohardness values are within the limits prescribed by the powder manufacturer (Metco 307NS, Metco 308NS Nickel Graphite Powder, 2000, 10-115). The increased amperage resulted in the increased tensile bond strength of the NiAl/Ni-graphite coating system, leading to a better and more dense packing of particles at each other followed by a smaller proportion of pores. Layers deposited with a higher amperage are thicker as confirmed by metallographic examinations of samples.In addition, higher values of the macrohardness of Ni-graphite layers deposited with a higher amperage indicate a greater cohesive strength of the layers, as confirmed by the results of tensile bond strength. The tensile bond strength for the NiAl / Ni-graphite coating system directly depends on the amperage (Fig. 3). All coating systems had good values of tensile bond strength, resulting from the exothermic reaction of $\mathrm{Al}$ and $\mathrm{Ni}$, which occurs during the deposition of Ni powder coated with Al. The 
exothermic reaction enables obtaining good adhesion strength with the substrate and good cohesion strength between the lamellae (Deevi,et al., 1997, pp. 335-344), (Mrdak, et al., 2004., pp. 321-326).

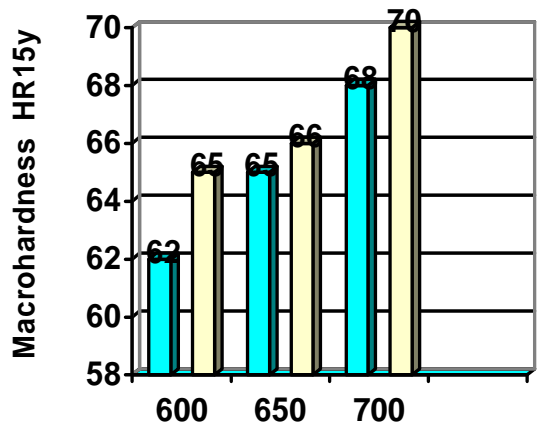

\section{$\square \mathrm{Ni}-25 \%$ graphite}

$\square \mathrm{Ni}$ - $15 \%$ graphite

Electric carrent $A$

Figure 2 - Macrohardness of Ni-graphite layers Slika 2 - Makrotvrdoća Ni-grafit slojeva

The coatings deposited with the highest amperage have higher tensile bond strength for $40 \mathrm{MPa}$ and $42 \mathrm{MPa}$, and the coatings deposited with the lowest amperage have the minimum tensile strength for $30 \mathrm{MPa}$ and $32 \mathrm{MPa}$. For all coatings, the fracture occurred along the boundary between the substrate and the bond layer. This means that the bond between the NiAl and Ni-graphite layers is good as well as the cohesive strength of Ni-graphite coating.
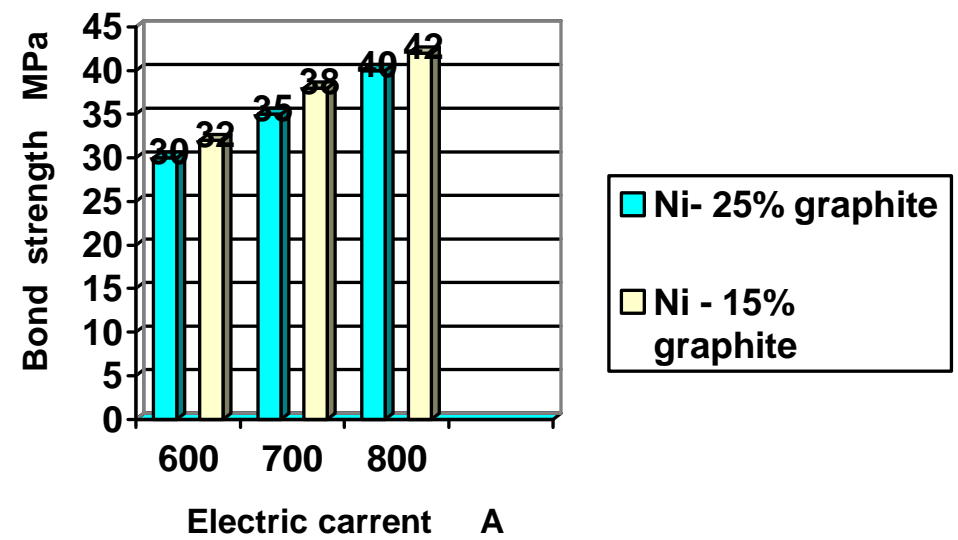

Figure 3 - Bond strength of $\mathrm{Ni}$-graphite layers Slika 3 - Čvrstoća spoja Ni-grafit slojeva 
Microstructures of the coating systems $\mathrm{NiAl} / \mathrm{Ni}-25 \%$ graphite and $\mathrm{NiAl} / \mathrm{Ni}-15 \%$ graphite deposited with the amperage of $700 \mathrm{~A}$ are shown in Figs. 4 and 5.

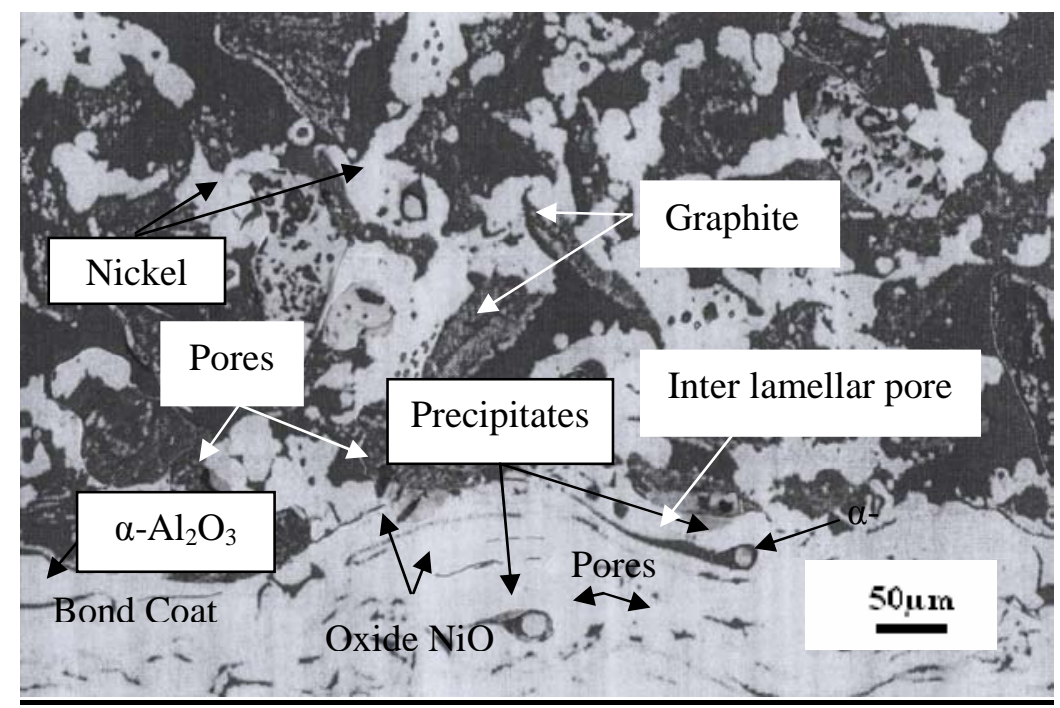

Figure 4 - Microstructure of NiAl / Ni-25\% graphite layers deposited with 700A Slika 4 - Mikrostruktura NiAl / Ni-25\% grafit slojeva deponovanih sa 700A

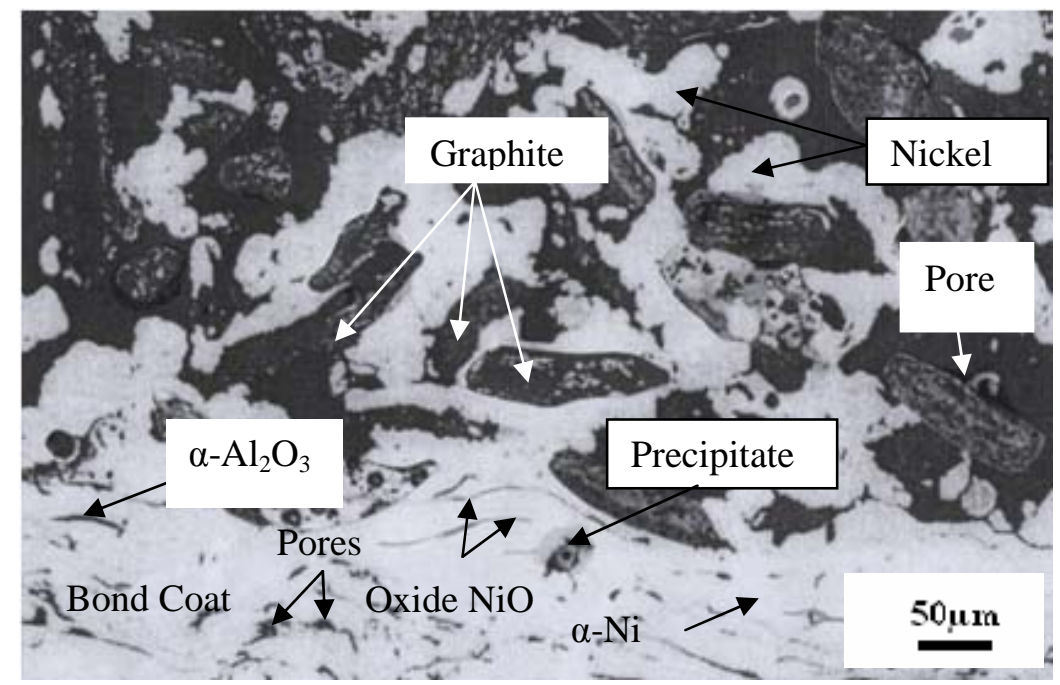

Figure 5 - Microstructure of $\mathrm{NiAl} / \mathrm{Ni}-15 \%$ graphite layers deposited with 700A Slika 5 - Mikrostruktura NiAl / Ni-15\% grafit slojeva deponovanih sa 700A 
NiAl bonding layers are deposited uniformly without interruption on the substrate. In the NiAl layer structure, unmelted powder particles are not visible In photomicrographs, a smaller proportion of spherical precipitates is observed as a consequence of the collision of the melted powder particles with the substrate. At the time of the collision, melted particles break at the ends and remain as residue in the coating. A small proportion of the interlamellar spherical pores is visible through the layers. The structure of bonding coatings is lamellar and consists of a solid solution of light gray nickel $\alpha-\mathrm{Ni}$. In the basis of the solid solution, thin oxide films of $\mathrm{NiO}$ and $\alpha-\mathrm{Al}_{2} \mathrm{O}_{3}$ are clearly visible, formed between the base lamellae originating from oxidation of $\mathrm{Ni}$ and $\mathrm{Al}$ in the process of solidification and compressed air cooling.Coatings are dense and homogeneous with a small proportion of pores in the coating layers. Microcracks and macrocracks are not visible through coating layers. Micro pores and microcracks are not present on the interface between the NiAl bond layers and Ni-graphite layers.This suggests a good bonding of the $\mathrm{Ni}$ from the $\mathrm{NiAl}$ coating with the $\mathrm{Ni}$ from the Ni-graphite coating.

$\mathrm{Ni}$-graphite layers are uniformly deposited on the bonding layers with the nickel lattice in the coating. In photomicrographs 4 and 5 , nickel lattices are light gray and marked with black arrows. Ni particles are melted and well-bonded to form the basis of the Ni-graphite coating.The $\mathrm{Ni}$ lattices are an indication that the powder particles were melted evenly and properly deposited in the coating layers. Among the deposited $\mathrm{Ni}$ particles there are black graphite particles marked with white arrows. In the microstructure, there are graphite particles which retained the morphology before the deposition. This is an indication that graphite did not burn in the deposition process. Graphite particles are surrounded and encapsuled with $\mathrm{Ni}$ particles which prevent graphite from falling out. Graphite acts as a solid lubricant and, in the contact with the compressor blades, due to friction, conducts heat away rapidly, which further reduces the input stress in coatings. In photomicrographs, small pores with a small share are observed in the graphite areas. The microstructure does not reveal the vacancies due to extracted graphite particles. Micro-cracks and rough pores are not observed through coating layers, which is in accordance with the mechanical properties of layers.

Figs. 6 and 7 show the microstructures of the Ni-25\% graphite and $\mathrm{Ni}-15 \%$ graphite coating layers without bond layers deposited with the current of 700A, which showed the best mechanical and structural characteristics. 


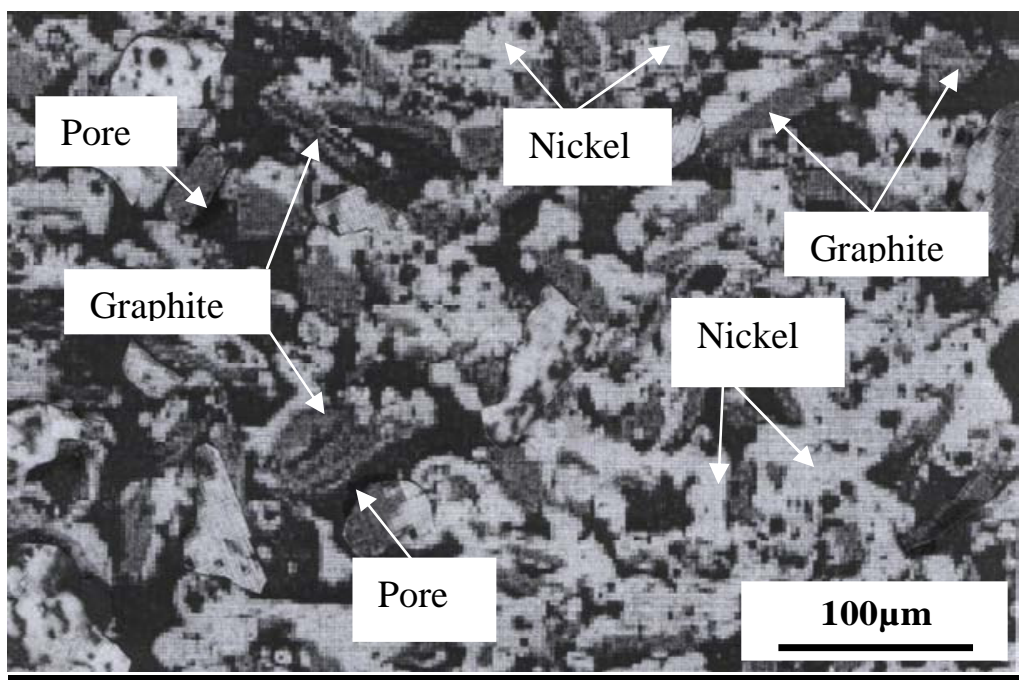

Figure 6 - Microstructure of $\mathrm{Ni}-25 \%$ graphite layers deposited with $700 \mathrm{~A}$ Slika 6 - Mikrostruktura Ni-25\% grafit slojeva deponovanih sa 700A

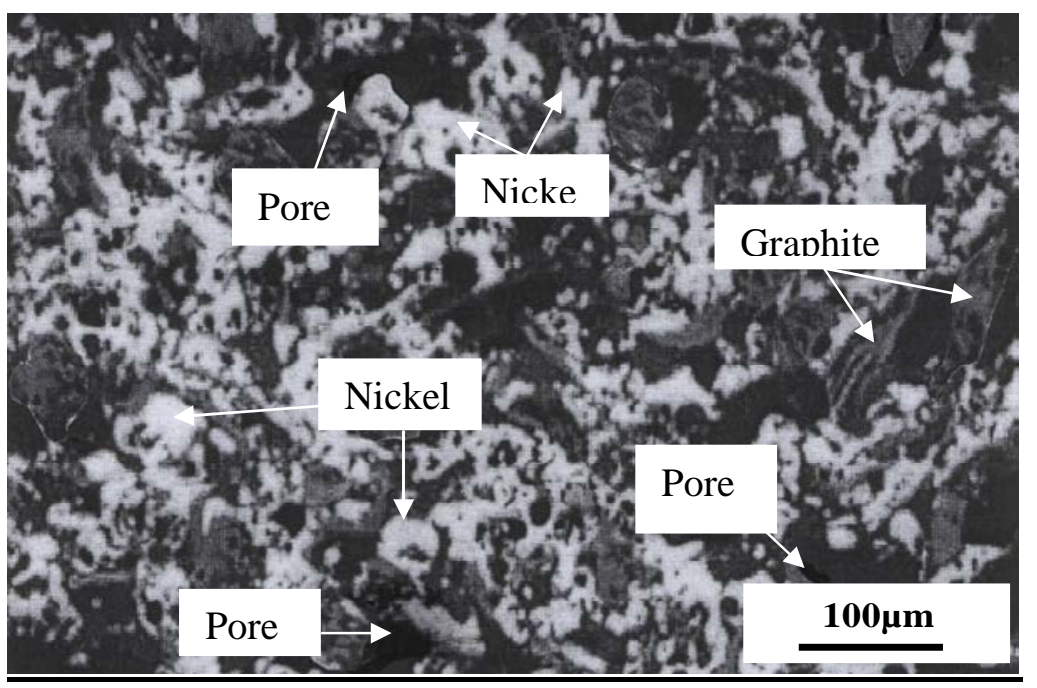

Figure 7 - Microstructure of Ni-15\% graphite layers deposited with 700A Slika 7 - Mikrostruktura Ni-15\% grafit slojeva deponovanih sa 700A

Photomicrograph 6 shows the light gray Ni lattice which is, due to a higher content of $\mathrm{Ni}$, more noticeable than the microstructure of the coating with a lower content of $\mathrm{Ni}$ shown in Fig. 7. Unmelted Ni particles and microcracks are not present in the Ni-graphite layers. Graphite with a 
small share of pores is present in the layers. The Ni metal base which gives strength, toughness, resistance to oxidation, corrosion and erosion has a good interlamellar bond. Graphite as solid lubricant and a means to control porosity is evenly distributed in the coating layers (Guilemany, et al., 2001, pp. 1115-1118). It is surrounded and encapsuled by the $\mathrm{Ni}$ metal base which is very important because graphite increases the coating resistance to thermal shocks, which is one of the key criteria that Ni-graphite sealing coatings must meet in exploitation. Uniformly deposited graphite in the $\mathrm{Ni}$ basis prevents the transfer of the coating to the blades and chipping of the paint, and reduces coating erosion.

Fig. 8 shows a photomicrograph of the fracture morphology of the $\mathrm{Ni}-25 \%$ graphite layers deposited with 700A.

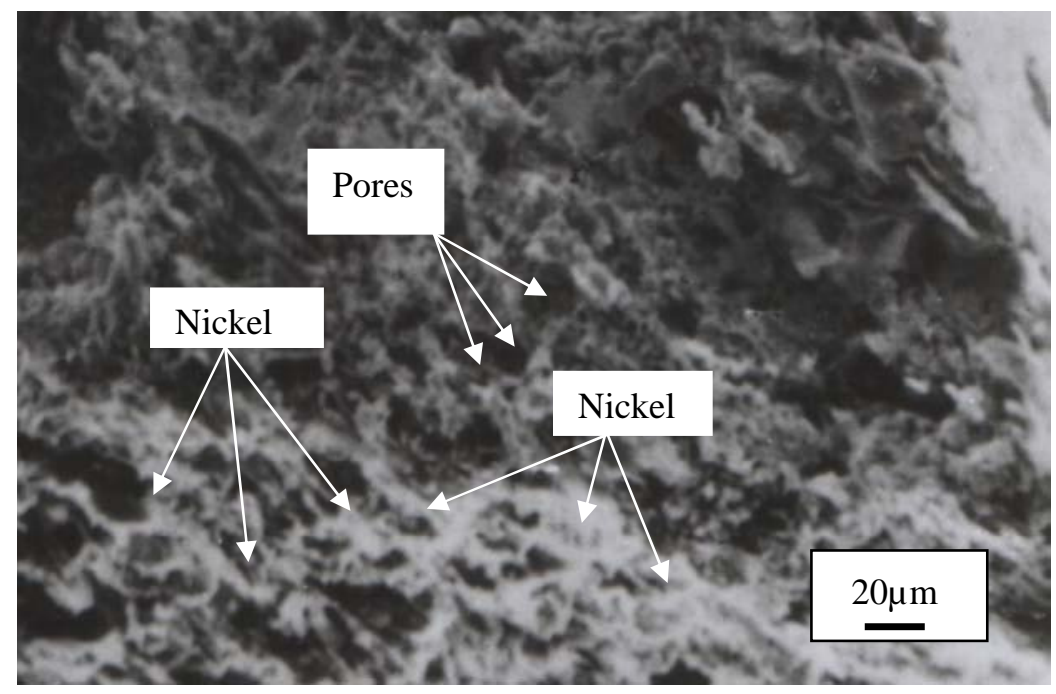

Figure 8 - SEM photomicrograph of the fracture morphology of the $\mathrm{Ni}-25 \%$ graphite coating deposited with 700A

Slika 8 - SEM mikrofotografija morfologije loma Ni-25\% grafitr prevlake deponovane sa $700 \mathrm{~A}$

The Ni fracture morphology consisting of a solid solution $\alpha-\mathrm{Ni}$ is visible on the fracture. The fracture is tough and graphite particles are not visible in the microstructure of the fracture due to poor adhesion to the $\alpha-\mathrm{Ni}$ particles. The bond strength between Ni lamellae and graphite is weak because of different types of materials. Graphite is soft and non-metallic material. The carbon atoms in graphite are arranged in the vertices of regular hexagons that form the layers. Each carbon atom within a layer is surrounded by three nearest neighbors with mutual covalent bonds. Weak Van der Waals forces act between the layers. Because of its 
layered structure, it splits easily along the layers under force. A brittle bond between the particles of graphite and the $\alpha-\mathrm{Ni}$ metal grains caused the fracture of graphite and its falling out from basis. The vacancies in the $\alpha-\mathrm{Ni}$ base that were previously filled with graphite are clearly visible in photomicrographs. During solidification, the a-Ni particles formed a structure of the coating in a form of a continuous lattice that encloses graphite particles, which, during exploitation, reduces erosion of the coating, as well as coating transfer onto the blades and prevents coating chipping.

\section{Conclusion}

Tests of $\mathrm{Ni}-25 \%$ graphite and $\mathrm{Ni}-15 \%$ graphite sealing coatings in the system with the NiAl bond coating have shown that amperage affects the mechanical properties and the structures of Ni-graphite deposited layers. NiAl bonding layers are homogeneous, dense and consist of $\alpha-\mathrm{Ni}$, $\mathrm{NiO}$ and $\alpha-\mathrm{Al} 2 \mathrm{O} 3$. The values of microhardness of the bonding $\mathrm{NiAl}$ layers were above the prescribed standard values indicating a complete reaction of $\mathrm{Al}$ and $\mathrm{Ni}$ particles. The good $\mathrm{NiAl}$ bond with $\mathrm{Ni}$-graphite coatings was confirmed in the tests of tensile bond strength. For Nigraphite coatings, the layers deposited with the highest amperage had the highest macrohardness values. Macrohardness values for $\mathrm{Ni}-25 \%$ graphite and $\mathrm{Ni}-15 \%$ graphite were within the prescribed limits. The tensile strength of the Ni-graphite coating bond in the system with the bond coating is directly related to the amperage. The layers deposited with the highest current strength had the highest values of tensile bond strength.

The qualitative analysis of the Ni-graphite layers in the cross-section showed that the coatings were evenly and continuously deposited on the bonding layers. Micro and macrocracks are not present at the interface due to which the coatings have good adhesion with the bonding layers.

The $\mathrm{Ni}-25 \%$ graphite and $\mathrm{Ni}-15 \%$ graphite microstructures showed a uniform structure throughout the whole length of the samples. The base of the Ni-graphite coatings consists of the a-Ni solid solution with a continuous lattice. The microstructure of $\alpha-\mathrm{Ni}$ is light gray and that of graphite is black. The graphite particles are surrounded and encapsuled by lamellae of Ni solid solution which prevent fallout of graphite particles during exploitation.

Due to a higher heat content of the plasma jet, the Ni-graphite layers deposited with the highest strength of electric current showed higher values of mechanical characteristics that are consistent with the microstructures. 
The results indicate that the intensity of electric current can affect the mechanical properties and the structure of Ni-graphite layers. The application of Ni-graphite coatings as a new sealing system on the low and high pressure parts of the compressors of TV2-117A engines provided the maximum flow of the air the temperature of which was $100-125^{\circ} \mathrm{C}$ through the compressor at a pressure of 7 bar with reduced fuel consumption.

\section{Literature}

Deevi, S.C., Sikka, V.K., Swindeman, C.J., and Seals, R.D., 1997, Reactive Spraying of Nickel - Alurninide Coatings, Journal of Thermal Spray Technology, 6(3), pp. 335-344.

Demasi, J.T., Protective coating in the gas turbine engine, Surf.Coat.Technol., 1994, Protective coating in the gas turbine engine, Technol. 68-69, pp. 1-9.

Guilemany, J.M., Navarro, J., Lorenzana, C., Vizcaino, S., Miguel, J. M., 2001, Tribological behaviour of abradable coatings obtained by atmospheric plasama spraying (APS), Pub.ASM international,Materials Park,OH-USA, pp. 1115-1118.

Mrdak, M., Kakaš, D., Pović, Đ., Struktura i svojstva nikal-aluminid prevlaka deponovanih plazma spreingom, Konferencija Istraživanje i razvoj mašinskih elemenata i sistema, IRMES '04, Kragujevac, 2004, pp. 321-326.

Nasr, H., 1988, Some Areas of Application of Plasma Spry Coatings in the Field of Aviation, Proceedings of the 1st Plasma-Technik Symposium, Lucerne, Switzerland, 3, pp. 75-84.

Novinski, E.R., 1991, The design of thermal sprayed abradable seal coatings for gas turbine engines, Proceedings of $4^{\text {th }}$ National Thermal Spray Conference, USA, pp. 451-454.

Novinski, E.R., 1990, Process parameter impact on the physical properties of an advanced abradable coating. Proceedings of $3^{\text {rd }}$ National Thermal Spray Conference, USA, pp. 151-157.

Oka, T., 1990, Basic characteristic of different abradable coatings, Proceedings of International Thermal Spraying Conference, Germany, pp. 58-67.

Svantesson, J., Wigren, J., A., 1992, A Study of Ni-5wt. NiAl Coatings Produced from Different Feedstock Powder, Journal of Thermal Spray Technology, 1 (1).

Tosnar, L., 1988, Plasma Sprayed Seal Coatings, Proceedings of the 1st Plasma-Technik Symposium, Lucerne, Switzerland, 2, pp. 257-262.

$\mathrm{Yi}, \mathrm{M} ., 1999$, Friction and wear behaviour and abradability of abradable seal coating, Wear 231, pp. 47-53.

Yi, M., 1997, Erosion wear of AlSi-graphite and Ni/graphite abradable seal coating, Trans. Nonferrons Met. Soc. China (English letter), 8 (2), pp. 99-102.

Metco 307NS, Metco 308NS Nickel Graphite Powder, 2000,Technical Bulletin 10-115, Sulzer Metco.

Metco 450NS Nickel /Aluminum Composite Powder, 2000, Technical Bulletin 10-136, Sulzer Metco.

Turbojet Engine - Standard Practices Manual (PN 582005), 2002., Pratt \& Whitney, East Hartford, USA. 
KARAKTERIZACIJA NIKAL-GRAFIT ZAPTIVNIH PREVLAKA U SISTEMU SA VEZNOM PREVLAKOM NIKAL-ALUMINIJUM

OBLAST: hemijske tehnologije

VRSTA ČLANKA: originalni naučni članak

\section{Sažetak:}

$U$ ovom istraživanju prikazane su mehaničke i strukturne karakteristike Ni-grafit zaptivki i efekat njihove primene na delovima kompresora niskog i visokog pritiska turbomlaznog motora TV2-117A. Prevlake su deponovane (APS) atmosferski plazma sprej postupkom. Izvršena je supstitucija zaptivnog materijala na radnim prstenovima kompresora, usmeravajućim aparatima $i$ prednjem telu kompresora turbomlaznog motora TV2-117A, da bi se obezbedio maksimalan protok vazduha temperature od $100-125^{\circ} \mathrm{C}$ kroz kompresor pod pritiskom od 7 bara. Meke zaptivke su formirane kao dvojni sistemi koji se sastoje od donjeg veznog sloja na bazi NiAl prevlake i gornjih zaptivnih prevlaka na bazi slojeva Ni-25\% grafita i Ni-15\%grafita. Mikrostrukture slojeva su procenjene na svetlosnom mikroskopu. Morfolofija čestica praha Ni-grafita i morfologija loma prevlake je ispitana na (SEM ) skening elektronskom mikroskopu. Mikrostrukturna analiza deponovanih slojevima je urađena u skladu sa standardom Pratt-Whitney. Procena mehaničkih karakteristika prevlaka je urađena ispitivanjem mikrotvrdoće veznih slojeva metodom $\mathrm{HV}_{0.3}$ i makrotvrdoće zaptivnih slojeva metodom HR15y. Čvrstoće spoja dvojnih sistema prevlaka su ispitane metodom kidanja na zatezanje. Efekat zaptivanja delova kompresora je ispitan u sklopu motora TV2-117A.

Uvod

Nove generacije turbo mlaznih motora imaju sve veće zahteve za boljom pouzdanošću rada i dužim resursom u eksploataciji. Cilj projektovanja i dizajniranja turbo mlaznih motora se zasniva na velikoj pogonskoj sili, visokoj efikasnosti i manjoj potrošnji goriva. Da bi se postigli postavljeni ciljevi, zazori između rotorskih lopatica i kućišta motora moraju da budu mali. Veoma dobro zaptivanje gasa koji protiče kroz motor smanjuje gubitke gasa uzrokovane curenjem. Za izradu zaptivnih prevlaka najčešće se koriste termo sprej procesi zbog jednostavnog procesa, lake popravke komponenti, lakog podešavanja osobina prevlaka i dobre efikasnosti zaptivanja. Takođe, zaptivke mogu da obezbede toplotnu izolaciju kućišta, i smanje uticaj visokih temperatura gasa i goriva na kućište. Za tu namenu se koriste višekomponentni prahovi od kojih se proizvode zaptivne prevlake. Po hemijskom sastavu prevlake se uglavnom sastoje od metalne faze i nemetalne faze za samo - podmazivanje sa visokom poroznošću. Najvažnija svojstva koja treba da poseduju zaptivne prevlake su velika otpornost na trošenje struganjem lopatica $i$ otpornost na eroziju gasa i stranih čestica koje su prisutne u gasu.

Na komponentama niskog i visokog pritiska kompresora turbomlaznih motora se primenjuju meke prevlake koje su otporne na erozi- 
ju i u sklopu sa lopaticama uzrokuju niskoenergetske uslove trenja. Prevlake su projektovane tako da se u eksploataciji habaju, a da pri tome ne uzrokuju habanje i oštećenja lopatica ili šavova labirinta. Prevlake su po svojoj strukturi pogodne za ekscentrične sklopove jer mogu da kompenzuju promene tolerancija uzrokovane mašinskom obradom. Prevlake na bazi nikal - grafita omogućuju podešavanje zazora na najmanju vrednost, a sa time i na poboljšanje performansi motora. Preciznost u toleranciji mašinske obrade se odražava i na znatno smanjenje oštećenja lopatica i smanjenje potrošnje goriva.

Kod zaptivnih sistema koji se troše, potrebno je uravnoteženje između trošenja materijala pod uticajem toplote, završne površinske obrade, otpornosti na eroziju i otpornosti na habanje. Sa plazma sprej parametrima depozicije prahova omogućena je kontrola navedenih kritičnih karakteristika. Plazma sprej proces depozicije omogućuje kontrolu poroznosti, gustine i debljine prevlaka da bi se dobili zaptivni slojevi traženih karakteristika.

Meke zaptivke se formiraju kao dvojni sistemi. Za izradu donjeg veznog sloja najčešće se koristi kompozitni prah NiAl. Obložene čestice Ni sa česticama Al omogućuju egzotermnu reakciju uz oslobađanje toplote koja uvećava čvrstoću veze prevlake sa supstratom i gornjom prevlakom. Obloženi prah Ni/Al proizvodi prevlake koje se sastoje od slobodnog $\mathrm{Al}$ čvrstog rastvora $\alpha-\mathrm{Ni}$ i oksida $\mathrm{NiO}$ i $\mathrm{Al}_{2} \mathrm{O}_{3}$.

Uloga veznog sloja je da omogući dobru adheziju sa osnovnim materijalom i vezu sa gornjim zaptivnim slojem. Spoljni sloj ima osnovnu funkciju zaptivanja. Prahovi Metco 307NS i 308NS se koriste za izradu zaptivnih prevlaka koje se primenjuju do $480^{\circ} \mathrm{C}$ koje do ovih temperatura imaju veliku postojanost na oksidaciju, habanje i nagle promene temperatura.

Pre depozicije praha radi se predgrevanje podloge u rasponu temperature od $90-120^{\circ} \mathrm{C}$. Temperatura predgrevanja je veoma bitna kao i kontrola temperature $u$ toku depozicije praha jer bitno utiče na tvrdoću deponovanih slojeva, na udeo pora i čvrstoću spoja između prevlake $i$ supstrata. Sa predgrevanjem podloge povećava se makrotvrdoća i čvrstoća spoja dok se smanjuje poroznost prevlaka. Temperatura podloge u toku depozicije ne sme da pređe $180^{\circ} \mathrm{C}$.

Cilj istraživanja je bio da se plazma sprej tehnologijom i nikal grafit prevlakama ispita efikasnost zaptivanja kompresora turbomlaznog motora TV2117A. Svetska istraživanja u ovoj oblasti su uticala na primenu Ni-grafit prevlaka u postupku remonta kompresora turbomlaznog motora TV2-117A. Izvršena je supstitucija postojećeg zaptivnog materijala na radnim prstenovima kompresora, usmeravajućim aparatima i prednjem telu kompresora. Ispitivanja kompresora na ispitnoj stanici su potvrdila da novi sistem zaptivanja obezbeđuje maksimalan protok vazduha temperature od $100-125^{\circ} \mathrm{C} \mathrm{kr}$ oz kompresor pod pritiskom od 7 bara uz smanjenu potrošnju goriva.

Materijali i eksperimentalni detalji

Materijal supstrata za deponovanje dvojnih zaptivnih sistema prevlaka za ispitivanje mehaničkih i strukturnih karakteristika je bio od nerđajućeg čelika X15Cr13 (EN 1.4024). Materijal je korišćen u termički neobrađenom 
stanju. Za proizvodnju veznih slojeva koristio se prah firme Sulzer Metco sa oznakom Metco 450NS. Prah se sastoji od 95,5\% nikla i 4,5\% Al sa rasponom granulata čestica praha od 45-88 $\mu \mathrm{m}$. Prevlake su samovezujuće $i$ guste sa visokim vrednostima čvrstoće spoja. Za izradu zaptivnih prevlaka korišćeni su prahovi sa oznakama Metco 307NS i Metco 308NS. Čestice prahova se sastoje od grafitnih jezgara obloženih finim česticama nikla. Prah Metco 307NS se sastoji od 75\% Ni i 25\% grafita sa rasponom granulata čestica praha od 30-90 $\mu \mathrm{m}$. Temperatura topljenja praha je $1455^{\circ} \mathrm{C}$. Prah Metco 308NS je po hemijskom sastavu identičan i razlikuje se po sa-

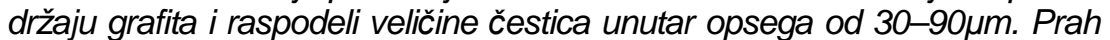
$308 N S$ se sastoji od 85\% Ni i 15\% grafita sa istom temperaturom topljenja kao prah Metco 307NS. Na sl. 1 je prikazana SEM mikrofotografija na kojoj se vidi morfologija čestica praha Ni-25\% grafit. Čestice praha su nepravilnog oblika. Čestice grafita su tamne boje okružene niklom svetlo sive boje.

Proces nanošenja slojeva prevlaka na uzorcima i delovima kompresora je urađen plazma sprej postupkom na atmosferskom pritisku (APS). Prevlake su nanete na uzorcima i delovima koji su ohrapavljeni belim korundom veličine čestica od 0,7-1,5 mm. Pre depozicije osnove su predgrejane na temperaturi od $90-120^{\circ} \mathrm{C}$. Za izradu prevlaka koristio se atmosferski plazma sprej sistem (APS) firme Plasmadyne. Zbog geometrije delova: usmeravajućeg aparata od IV-IX stepena, prednjeg tela kompresora i radnih prstenovima kompresora od $V-X$ stepena, deponovanje prahova je urađeno sa specijalnim plazma pištoljem MINI-GUN II dimenzija $\Phi 25$ X $600 \mathrm{~mm}$. Plazma pištolj se sastojao od : anode A 2084-F65 ; katode K 1083A-129 i gas injektora GI 2084 B-103. Vezni slojevi su deponovani sa mešavinom plazma gasovima Ar-He. Za deponovanje Ni-grafit čestica kao gas je korišćen argon sa jačinama električne struje od 600,650 i 700A. Na uzorcima za ispitivanje karakteristika prevlaka, vezni slojevi NiAl su deponovani sa udelom depozita od 0,025 $\mu \mathrm{m}$ po jednom prolazu plazma pištolja sa ukupnom debljinom od $0,15 \mathrm{~mm}$. Zaptivni slojevi Ni-grafit su deponovani sa udelom depozita od $0,12 \mathrm{~mm}$ po jednom prolazu plazma pištolja sa ukupnom debljinom od $0,36 \mathrm{~mm}$. Na prednjem telu kompresora deponovana je prevlaka Ni-25\% grafit, dok je na radnim prstenovima i usmeravajućim aparatima kompresora deponovana prevlaka Ni-15\% grafit. Na delovima kompresora deponovane su prevlake sa ukupnim debljinama od $2.3 \mathrm{~mm}$. Detaljne vrednosti sprej parametara su prikazane u tabeli 1.

Mehaničke i mikrostrukturne karakterizacije dobijenih prevlaka su izvršene prema standardu Pratt \& Whitney. Za merenje tvrdoće i metalografska ispitivanja korišćeni su pravougaoni uzorci $70 \times 20 \times 1,5 \mathrm{~mm}$, dok su za zateznu čvrstoću korišćeni cilindrični uzorci $\varnothing 25 \times 50$ mm. Mikrostrukturna analiza prevlaka urađena je na svetlosnom mikroskopu, dok je morfologija praha i morfologija loma prevlake urađena na SEM-u (skening elektronskom mikroskopu).

Merenje mikrotvrdoće veznih slojeva je urađeno korišćenjem Vikers dijamant piramide indenter i 300 grama opterećenje $\left(H V_{0.3}\right)$. Merenje je obavljeno u pravcu duž lamela, u sredini i na krajevima uzorka. Na tri mesta sprovedena su tri očitavanja a dobijeni rezultati su usrednjeni. 
Makrotvrdoća Ni-grafit prevlaka je urađena korišćenjem Rockwell čelične kugle prečnika 12,7 mm i opterećenje od 15 kg (HR15y). Makrotvrdoća prevlaka je merena duž slojeva. Da bi se procenila homogenost slojeva merenje je izvršeno u tri oblasti: $u$ sredini i na levom $i$ desnom kraju uzoraka. Prikazani rezultati makrotvrdoće su osrednjene vrednosti većeg broja merenja.

Testovi zatezne čvrstoće spoja su vršeni na sobnoj temperaturi na hidrauličnoj opremi sa brzinom od $10 \mathrm{~mm} / \mathrm{min}$, za sva ispitivanja. Geometrija uzoraka je u skladu sa ASTM C633 standardom. Za svaki grupu uzoraka urađene su po tri epruvete a dobijeni rezultati su usrednjeni.

\section{Rezultati i diskusija}

Vrednosti mikrotvrdoće veznih slojeva NiAl su bile u rasponu od 203-210HV ${ }_{0.3}$ i iznad su vrednosti propisanih standardom PWA (in.140 $H V_{0.3}$ ). To govori da je u procesu depozicije došlo do potpune reakcije čestica Al i Ni. Vrednosti makrotvrdoće Ni-grafit slojeva su prikazane na slici 2. i čvrstoće spoja sistema NiAl / Ni-grafit prevlaka na slici 3. Vrednosti električne struje koje su u direktnoj vezi sa snagom napajanja plazma pištolja uticale su na vrednosti makrotvrdoće i čvrstoće spoja deponovanih slojeva. Slojevi deponovani sa najmanjom jačinom struje od 600 A su pokazali najniže vrednosti makrotvrdoće od 62 HRy za Ni-25\% grafit i 65 HRy za Ni-15\% grafit prevlaku. Najviše vrednosti makrotvrdoće od 68 HRy za Ni-25\% grafit i 70 HRy za Ni-15\% grafit prevlaku su pokazali slojevi deponovani sa najvećom jačinom električne struje od 700A. Za sve deponovane prevlake dobijene su vrednosti makrotvrdoće u granicama propisanim od proizvođača praha.

Zatezne čvrstoće spoja za sistem prevlaka NiAl / Ni-grafit su u direktnoj zavisnosti jačine struje (slika 3). Svi sistemi prevlaka su imali dobre vrednosti zatezne čvrstoće spoja koje proizilaze iz egzotermne reakcije Al i Ni koja se dešava za vreme depozicije praha Ni obloženog sa Al. Egzoterma reakcija omogućuje da se dobije dobra adheziona čvrstoća sa supstratom i dobra među lamelarna koheziona čvrstoća. Prevlake deponovane sa najvećom jačinom struje imaju veću zateznu čvrstoću spoja $40 \mathrm{MPa}$ i $42 \mathrm{MPa}$, a prevlake deponovane sa najmanjom jačinom struje imaju najmanju zateznu čvrstoću spoja $30 \mathrm{MPa}$ i $32 \mathrm{MPa}$. Za sve prevlake se prelom dešavao duž granice između supstrata i veznog sloja. To znači da je dobra veza između NiAl i Ni-grafit slojeva kao i koheziona čvrstoća Ni-grafit prevlaka.

Vezni slojevi NiAl su deponovani uniformno bez prekida na supstratima. U strukturi NiAl slojevima se ne uočavaju neistopljene čestice praha. Na mikrofotografijama se u manjem udelu uočavaju precipitati sfernog oblika koji su posledica sudara istopljenih čestica praha sa supstratom. U trenutku sudara istopljena čestica se na krajevima odlama i ostaje kao talog u prevlaci. Kroz slojeve se u manjem udelu uočavaju sferne $i$ inter lamelarne pore. Struktura veznih prevlaka je lamelarna $i$ sastoji se od čvrstog rastvora nikla $\alpha$ - Ni svetlo sive boje. U osnovi čvrstog rastvora jasno se uočavaju tanki oksidni filmovi NiO i $\alpha-\mathrm{Al}_{2} \mathrm{O}_{3}$ 
formirani između lamela osnove koji potiču od oksidacije Ni i Al u procesu očvršćavanja i hlađenja komprimovanim vazduhom.

Ni-grafit slojevi su ravnomerno deponovani na veznim slojevima sa mrežom nikla u prevlaci. Na mikrofotografijama 4 i 5 . mreže Ni su svetlo sive boje obeležene strelicama crne boje. Čestice Ni su dobro istopljene $i$ međusobno povezane koje čine osnovu Ni-grafit prevlaka. Mreže Ni su pokazatelj da su se čestice praha ravnomerno topile i pravilno deponovale u slojevima prevlaka. Između deponovanih Ni čestica prisutne su čestice grafita crne boje obeležene belim strelicama. U mikrostrukturi se uočavaju grafitne čestice koje su zadržale morfologiju pre depozicije. To je pokazatelj da u procesu depozicije nije došlo do sagorevanja grafita. Cestice grafita su okružene i zatvorene česticama Ni koje onemogućuju ispadanje grafita koji ima funkciju čvrstog sredstva za podmazivanje i koji u kontaktu sa lopaticama kompresora usled trenja brzo odvodi toplotu što znatno smanjuje unošenje napona u prevlakama.

Na slikama 6 i 7. su prikazane mikrostrukture slojeva Ni-25\% grafit i Ni-15\% grafit prevlaka bez veznih slojeva deponovanih sa jačinom električne struje od 700A koji su pokazali najbolje mehaničke i strukturne karakteristike. Na mikrofotografiji 6. se vidi mreža Ni svetlo sive boje koja je zbog većeg sadržaja Ni izraženija u odnosu na mikrostrukturu prevlake sa manjim sadržajem Ni prikazane na slici 7.

U Ni-grafit slojevima nisu prisutne nestopljene čestice Ni i mikro pukotine. U slojevima je prisutan grafit sa malim udelima pora. Metalna osnova Ni koja prevlakama daje čvrstoću, žilavost, otpornost na oksidaciju, koroziju i eroziju ima dobru među lamelarnu vezu. Grafit kao čvrsto mazivo i sredstvo za kontrolu poroznosti je ravnomerno raspoređen u slojevima prevlaka. Okružen je i zatvoren metalnom osnovom $\mathrm{Ni}$ što je veoma bitno jer grafit povećava otpornost prevlake na termo šokove koji je jedan od ključnih kriterijuma koje Ni-grafit zaptivne prevlake moraju da zadovolje u eksploataciji.

Na slici 8. je prikazana mikrofotografija morfologije loma Ni-25\% grafit slojeva deponovanih sa 700A. Na prelomu se vidi morfologija loma Ni koji se sastoji od čvrstog rastvora a-Ni. Prelom je žilav i u mikrostrukturi preloma se ne uočavaju čestice grafita zbog slabe adhezije sa česticama $\alpha$-Ni. Sila veze između lamela Ni i grafita je slaba zbor različitog tipa veze materijala. Grafit je mek i nemetalni materijal. Atomi ugljenika u grafitu su raspoređeni u temenima pravilnih šestouglova koji obrazuju slojeve. Svaki atom ugljenika, u okviru jednog sloja, okružen je sa tri najbliža suseda, između kojih postoje kovalentne veze. Između slojeva deluju slabe Van der Valsove sile. Usled svoje slojevite strukture, pod dejstvom sile lako se cepa duž slojeva. Slaba veza između čestica grafita i metalnih zrna $\alpha$-Ni uzrokovala je pri lomu cepanje grafita $i$ ispadanje iz osnove. Na mikrofotografiji se jasno vide prazna mesta u osnovi $\alpha-N i$ koja su bila ispunjena grafitom. Čestice $\alpha-N i$ su očvršćavanjem formirale strukturu prevlake oblika neprekidne mreže koja zatvara čestice grafita, što u eksploataciji smanjuje eroziju prevlake, prenos prevlake na lopatice i sprečava odlamanje prevlake. 
Zaključak

Ispitivanja zaptivnih prevlaka Ni-25\% grafit i Ni-15\% grafit u sistemu sa veznom prevlakom NiAl su pokazala da jačinama električne struje utiče na mehaničke karakteristike $i$ strukture deponovanih slojeva Ni-grafita.

Vezni slojevi NiAl su homogeni, gusti i sastoje se od $\alpha-\mathrm{Ni}$, NiO i $\alpha-\mathrm{Al}_{2} \mathrm{O}_{3}$. Vrednosti mikrotvrdoće veznih slojeva NiAl su bile iznad vrednosti propisanih standardom što ukazuje na potpunu reakciju čestica Al $i$ Ni. Veza NiAl sa Ni grafit prevlakama je dobra što su potvrdila ispitivanja zatezne čvrstoće spoja.

Za Ni-grafit prevlake, slojevi deponovani sa najvećom jačinom struje su imali najveće vrednosti makrotvrdoće. Vrednosti makrotvrdoće za Ni-25\% grafit i Ni-15\% grafit su bile u propisanim granicama.

Zatezna čvrstoća spoja Ni-grafit prevlaka u sistemu sa veznom prevlakom u direktnoj je vezi sa jačinom električne struje. Slojevi deponovani sa najvećom jačinom struje su imali najveće vrednosti zatezne čvrstoće spoja..

Kvalitativna analiza Ni-grafit slojeva na poprečnom preseku je pokazala da su prevlake ravnomerno i bez prekida deponovane na veznim slojevima. Na interfejsu nisu prisutne mikro i makro pukotine zbog čega prevlake imaju dobru adheziju sa veznim slojevima.

Mikrostrukture Ni-25\% grafit i Ni-15\% grafit su pokazale uniformnu strukturu po celoj dužini uzoraka. Osnova Ni-grafit prevlaka se sastoji od $\alpha$-Ni čvrstog rastvora koja ima kontinualnu mrežu. Mikrostruktura $\alpha-N i$ je svetlo sive boje a grafita crne boje. Čestice grafita su okružene i zatvorene lamelama čvrstog rastvora nikla koje onemogućuju ispadanje čestica grafita u eksploataciji.

Ni-grafit slojevi deponovani sa najvećom jačinom struje su zbog većeg toplotnog sadržaja mlaza plazme pokazale veće vrednosti mehaničkih karakteristika koje su u saglasnosti sa mikrostrukturama.

Prikazani rezultati ukazuju da se sa jačinom električne struje može uticati na mehaničke karakteristike i strukture Ni-grafit slojeva.

Primena Ni-grafit prevlaka kao novog sistema zaptivanja na delovima kompresora niskog i visokog pritiska motora TV2-117A obezbedila je maksimalan protok vazduha temperature od $100-125^{\circ} \mathrm{C} \mathrm{kroz}$ kompresor pod pritiskom od 7 bara uz smanjenu potrošnju goriva.

Ključne reči: atmosferski plazma sprej postupak (APS), zaptivanje, mikrostruktura, interfejs, mikrotvrdoća, makrotvrdoća, čvrstoća spoja.

Datum prijema članka/Paper received on: 20. 02. 2012.

Datum dostavljanja ispravki rukopisa/

Manuscript corrections submitted on: 05. 03. 2012.

Datum konačnog prihvatanja članka za objavljivanje/ Paper accepted for publishing on: 07. 03. 2012. 